\title{
CULTURE BASED TEACHING AND LEARNING FOR INDONESIAN AS A FOREIGN LANGUAGE IN YOGYAKARTA
}

\author{
Darmiyati Zuchdi*, Nurhadi \\ Yogyakarta State University, Indonesia \\ *e-mail: darmiyati@uny.ac.id
}

\begin{abstract}
The practice of culture-based teaching and learning Indonesian as a foreign language (T\&LIFL) has not been well managed and standardized. Therefore, this study attempted to investigate T\&LIFL at six universities in Yogyakarta. The investigation consisted of some cultural aspects in terms of program management, learning material, learning media, teaching approaches, methods, and strategies, learning assessment, and program evaluation. The research design was a mix method design. To collect data, it used questionnaires, interviews, and observations. The data then were analysis quantitatively and qualitatively. The research results were (1) T\&LIFL program management had not been culturebased, (2) T\&LIFL learning material had not been entirely culture-based, (3) there were not enough learning media reflected on culture, (4) approaches, methods, and strategies had not used learning models including language learning, language awareness, cultural awareness, and cultural experience, (5) the assessment of culture-based learning had not been carried out with process assessment, but some have already packed it in cultural festivals at the end of the program, and (6) there was no evaluation on T\&LIFL programs that explicitly evaluated program achievements on aspects of culture awareness, and experience.
\end{abstract}

Keywords: teaching, learning, Indonesian as a foreign language, cultural aspect

\section{PENGAJARAN DAN PEMBELAJARAN BERBASIS BUDAYA UNTUK BAHASA INDONESIA SEBAGAI BAHASA ASING DI YOGYAKARTA}

\begin{abstract}
Abstrak: Praktik pengajaran dan pembelajaran bahasa Indonesia sebagai bahasa asing (PBIA) berbasis budaya belum dikelola dengan baik. Oleh karena itu, penelitian ini bertujuan untuk menggali PBIA di enam universitas di Yogyakarta. Fokus penelitian ini pada enam aspek PBIA, yaitu manajemen program, materi pembelajaran, media pembelajaran, pendekatan, metode, dan strategi pembelajaran, dan penilaian pembelajaran, serta (6) evaluasi program PBIA. Penelitian ini menggunakan metode campuran kualitatif dan kuantitatif. Pengumpulan data menggunakan angket, wawancara, dan pengamatan kemudian data dianalisis secara kualitatif dan kuantitatif. Hasil penelitian disimpulkan sebagai berikut: (1) manajemen program PBIA belum berbasis budaya, (2) materi pembelajaran PBIA belum seluruhnya berbasis budaya, (3) media pembelajaran belum banyak yang berbasis budaya, (4) pendekatan, metode, dan strategi belum menggunakan model pembelajaran yang meliputi pembelajaran bahasa, kesadaran bahasa, kesadaran budaya, dan pengalaman budaya, (5) penilaian PBIA berbasis budaya belum dilakukan dengan penilaian proses, namun sudah ada yang mengemasnya dalam festival budaya pada akhir program, dan (6) evaluasi program PBIA belum mengevaluasi capaian program pada aspek kesadaran dan pengalaman budaya Indonesia/daerah secara eksplisit.
\end{abstract}

Kata kunci: pengajaran, pembelajaran, bahasa Indonesia sebagai bahasa asing, aspek budaya

\section{INTRODUCTION}

Teaching \& learning Indonesian as a foreign language program (henceforth T\&LIFL) is often called as Indonesian language for foreign speaker. Many universities, especially those that have language education faculties, develop and implement this program. The program is organized for foreign students who will study in universities as Developing Country Partnership participants and for others with different goals.

However, not all of universities that hold T\&LIFL programs meet the requirements of an effective program. Not only the program management has not been well managed, but 
also the learning material, learning media, approaches, methods, and strategies of assessment, and evaluation system are often unprepared. Therefore, all these things need an improvement so that a better quality of T\&LIFL program can be developed.

There are some evidences that T\&LIFL program in Indonesia has not been nationally coordinated and standardized. Each university runs on its own policy. However, the Language Agency has published six series of T\&LIFL textbooks. In 2015, there were three books published entitled Lentera 1, 2, 3. Then in 2016, there were six textbooks published: Sahabatku Indonesia: Tingkat Al (Novianti \& Nurlaelawati), Sahabatku Indonesia: Tingkat A2 (Maesaroh \& Ellis), Sahabatku Indonesia: Tingkat B1 (Rakhmawati \& Hakim), Sahabatku Indonesia: Tingkat B2 (Widia \& \& Sulistyaningsih), Sahabatku Indonesia: Tingkat C1 (Meilinawati \& Darmayanti), Sahabatku Indonesia: Tingkat C2 (Gunawan \& Muhamad). $\mathrm{A} 1$ and $\mathrm{A} 2$ are for beginners, B1 and B2 are for intermediated, and $\mathrm{C} 1$ and $\mathrm{C} 2$ are for advance level. Even so, those books need an innovation or supporting materials that cover more aspects of Indonesian culture. This is necessary because getting to understand and to practice Indonesian will be more effective if Indonesian language and culture are integrative learnt. Because learning Indonesian separated from culture is really not meaningful.

The culture in this study refers to Indonesian people way of life which represents in their daily activities, art, foods, crafts, and architects. Some of those were originally local culture then they were recognized as national culture. Understanding those cultures can make easier for the students to understand Indonesian as a foreign language. It is also strengthening the understanding of concepts or expressions learned because they are more strongly recorded in learner memory.

At the same time, students of doctoral program, Yogyakarta State University who took the Seminar on T\&LIFL Problems course, rarely had an experience related to the implementation of T\&LIFL programs. Some even do not know at all about it because there is no T\&LIFL program at the institutions where they used to be faculty members. Therefore, the implementation of this course needed to be innovated by involving the students in a research so that they directly participated in the process of investigating the implementation of T\&LIFL program. By doing this activity, hopefully they had competences to manage similar programs in their respective institutions. This course is organized in the form of collaborative learning.

Collaborative learning can transform collective thinking skills. In a team, people are used to thinking and acting together. Through regular practice, team members can learn together effectively. In an educational institution each study group is in one class. A class is a group of people who need each other to achieve a common goal, to develop shared competencies (Senge, 2000). In the context of studying in college or university, students in one class and lecturer are a team so that they can empower the class collaboratively to achieve the objectives of the lecture. Collaborative learning or learning in teams is based on the concept of unionseparate elements so that they can function that is oriented towards one another's awareness of the common goal. Although each person is a different individual, but his efforts tend to lead to goals that are generally the same (Senge, 2000). Therefore, a class can be designed so that students have an awareness of the common goals by being involved in activities to complete a joint task in the form of a project, commonly called project-based learning. This innovation is proven to be effective in helping students to do research. Wiyarsi, Hendayana, Firman, \& Anwar (2015) also found that collaborative learning with problem-solving activity was effective to improve students' knowledge.

Developing T\&LIFL program based on culture needs a synthesis between the learner's native culture, such as Japanese, American, or other cultures and Indonesian culture. However, it requires some considerations to include the learners' diverse cultural understanding in the T\&LIFL program as well as the lecturers' competence to teach Indonesian language intercultural or multicultural. The use of authentic material at the intercultural level is recommended not only to include texts produced by native speakers of the target language, but also those written and said by target language learners or T\&LILF program participants. This is intended to achieve communicative goals.

Byram \& Esarte-Sarries (1991) explained 
that there are two approaches in teaching foreign languages. The first approach is to use mother tongue of the learners as the language of instruction and the second approach is integrating learning languages and cultures in teaching by using the target language.

Figure 1 shows that there are four interconnected foreign language learning activities, namely: (1) Language learning: oriented to language skills and focusing on foreign languages using second/foreign languages as learning media. (2) Language awareness: oriented to socio-linguistic knowledge, focusing on comparison of languages, using learners' mother tongue as the language of instruction. (3) Cultural awareness: oriented to cultural knowledge by focusing on cultural comparisons. (4) Cultural experience: oriented to cultural experiences with a focus on foreign cultures in the target language. The model of teaching and learning Indonesian as a foreign language by integrating Indonesian or regional cultures as suggested by Byran \& Esarte-Sarries is not developed yet. Furthermore, as Indonesia has been internationally recognized of having cultural diversity by UNESCO, it is important to investigate how the implementation of culture-based teaching \& learning Indonesian as a foreign language in some institutions in Yogyakarta.

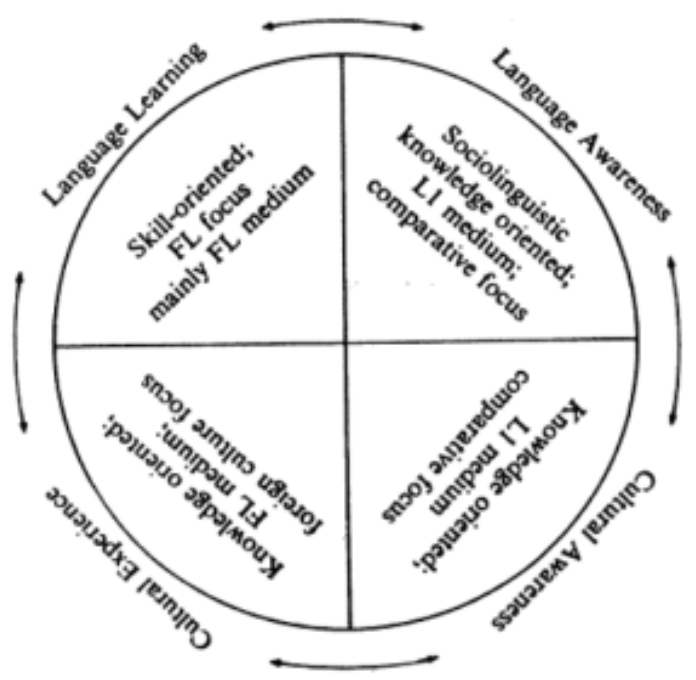

Figure 1. Foreign Language Education Model by Byram \& Esarte-Sarries (1991)

Researches on T\&LIFL being published through scientific journals are still limited. One of them that can be considered relevant to this current research is the development of Indonesian language teaching materials for foreign speakers, based on the results of the learning needs analysis by Suyitno (2014). He stated that T\&LIFL learners in general are adults who already have enough knowledge and insight. Some topics they want to learn are general topics such as environment, human relations, world events, etc. To accommodate interests and needs that may differ from one to the other, learning materials should be varies. Another T\&LIFL researcher, Taftiawati (2014), wrote about communicative strategy for South Korean students as beginner level learners in UPI (University of Indonesian Education). The study sought one alternative of L2 learning with one of the literary learning strategies. The strategy used was the adaption of the word games poetry model being known since 1993. The third research was from Gusnawaty \& Nurwati (2019) entitled "A Learning Model of Bahasa Indonesia as A Foreign Language Based on Local Intercultural Politeness". They found that the model was effective in overcoming the foreign learners' problems in oral interactions and improving their Indonesian language communicative competencies. Kusmiatun, Suyitno, HS, \& Basuki (2017) also conducted the same field research. They identified features of Indonesian for speakers of other languages learning for academic purposes. They found that T\&LIFL for academic purposes consisted of specific characteristics of learning components such as learning purpose, instructors' characteristics, learning material \& instructional strategy, and learning assessment.

Culture-based foreign language teaching and learning has also been discussed by Hsin (2003). He discussed on how to integrate culture in foreign language learning. There are some characteristics in foreign cultural learning: (a) it is like the process of interpretation aiming to make students understand such as: greeting the native speakers, act and respond in languages that are different from the way they do, both in fictional texts and in social life, (b) understanding of culture is constructive learning, and (c) cultural learning cannot be generalized as teachers do in teaching grammar. It needs to be focused on exploration and description. It is because the rules for creating meaning in culture are dynamic (Hsin, 2003). Foreign cultural content in teaching 
and learning also needs to be considered. It is because when they are separated from cultural roots, learners will find difficulties in socializing into the real context of the target language use. As an addition, dealing with the issue of global culture, foreign language learning content must be related to local culture (Hsin, 2003).

Those studies shared the object of the study about T\&LIFL learning. However, the focus of each research came from the experience of researchers who taught T\&LIFL on their respective campuses. This current research is different from those previous studies. It is because it emphasizes cultural aspects as the basis of T\&LIFL learning and investigates how those teaching and learning processes are conducted by integrating Indonesian culture, including their program management and evaluation.

This study is about the investigation of culture-based teaching \& learning Indonesian as a foreign language (T\&LIFL) at six universities in Yogyakarta. The aspects explored are how is the management of a culture-based T\&LIFL, how is the preparation of learning material of culture-based T\&LIFL, how is the development and utilization of culture-based T\&LIFL media, how are the approaches, method, and strategy used for culture-based T\&LIFL, how is the assessment of culture-based T\&LIFL learning, and how is the evaluation system of culturebased T\&LIFL program. All this information is important for developing a better T\&LIFL program. The previous study done by Gusnawaty \& Nurwati (2019) explored cultural aspects of T\&LIFL but it was limited in term of local intercultural politeness. Therefore, this study intends to explore cultural aspects of T\&LIFL in the broad sense.

\section{METHOD}

This research used is a mix method design. The object of the research is the implementation of culture-based T\&LILF program, including: (1) management, (2) material development, (3) media selection and development, (4) selection of approaches, methods and strategies, (5) assessment of learning, and (6) program evaluation. These six aspects are examined in general in six universities implemented T\&LILF program. Questionnaire was used for collecting quantitative data about the general implementation of the program while interview and observation were for qualitative data to explore deeply about the implementation of every aspect. Content validity and inter rater reliability were used in this study. Data was collected by six UNY doctoral students in six universities in Yogyakarta. They are Yogyakarta State University (UNY), Sunan Kalijaga State Islamic University (UIN SUKA), Indonesian Art Institute of Yogyakarta (ISI), Sanata Dharma University (USD), Ahmad Dahlan University (UAD), and Indonesia Islamic University (UII). Data collected by questionnaire were analyzed quantitatively by categorizing the responses, while data from interview and observation were analyzed qualitatively to describe the use of cultural aspects in the implementation of the existing T\&LIFL programs.

\section{RESULTS AND DISCUSSION Results}

The result of the study concerning of all aspects investigated is presented in the Table 1.

Based on the result of quantitative data analysis, it was obtained some findings as follows. As presented in table 1, the average score of the management aspect was 3.436 (from a maximum score of 4.0). It means that from the management aspects, the implementation of the T\&LILF was classified as good.

Overall, the management elements of the program consists of 5 questions, namely how often: (1) the institution revise the program, (2) the staff functions in accordance with the tasks assigned, (3) training is conducted for teaching staff to improve teaching competence, (4) the marketing system at this institution is well implemented, and (5) T\&LILF program is seen as a part of cultural diplomacy strategy. From the average score stated above, there are still things that need to be improved.

For T\&LILF learning material, the average score was 3.430 , while media development and utilization was at an average of 3.420. These scores were slightly lower than the average score of management elements. The score of approach, method, and strategy, was also lower than the average score of the management aspect, which were only 3.360 . The highest score was obtained from the elements of the assessment instrument which reached 3.685 , while the program evaluation system only reached 3.191, the lowest score compared to the other aspects. 
From these figures, the implementation of the T\&LILF on several campuses in Yogyakarta was categorized good, although there were still some elements needed to be improved or maximized.

Table 1. The Result of Quantitative Data Analysis

\begin{tabular}{clc}
\hline No & \multicolumn{1}{c}{$\begin{array}{c}\text { Implementation of T\&LILF } \\
\text { Elements }\end{array}$} & Score \\
\hline 1 & Program Management / Planning & 3.436 \\
2 & Material Development & 3.430 \\
3 & Media Development \& Utilization & 3.420 \\
4 & Approaches, Methods \& Strategies & 3.360 \\
5 & Assessment Instrument & 3.685 \\
6 & Program Evaluation System & 3.191 \\
\hline & Average score & 3.420 \\
\hline
\end{tabular}

From the results of interviews and field observations in the universities implementing T\&LILF program, the following findings were obtained.

UIN SUKA has Language Development Center with four divisions, including: (1) Arabic Language Division, (2) English Language Division, (3) Indonesian Language Division, and (4) Administrative Coordinator.

The educational background of T\&LILF teaching staffs in UIN SUKA were Indonesian language education. All the teaching staffs were faculty members in Indonesian language department, and all of them were native speakers. In addition, all foreign students studying at this institution were required to take T\&LIFL program.

This program was firstly implemented in 2013. The participants, mostly from Southern Thailand, some of them were master students. Sometimes they had difficulty writing a thesis because they had not enough writing skill in Indonesian language. Some of them even could not speak Indonesian, so unfortunately, they dropped out.

In general, the T\&LILF in UIN SUKA had not been designed culturally based. The only cultural aspects associated with this program were in the form of a fieldtrip to places related to Yogyakarta's peculiarities. For example, field trip to Parangtritis Beach, Malioboro Street, Prambanan Temple, Kasongan Craft, or warung (small restorant). Hopely, by this activity, participants could also learn firsthand the culture of Yogyakarta or Indonesia in general.

The peculiarities or could be said to be the main cultural elements for the implementation of T\&LILF in UIN SUKA should be one related to the Islamic elements. It is because UIN is a higher education institution based on Islamic education. However, these potential cultural elements had not been explored yet in developing T\&LILF program.

USD T\&LILF was relatively better organized. USD has language center that organized Asian language courses consisting of Indonesian, Javanese, Korean, Japanese, and Mandarin. T\&LILF teacher's educational background were Indonesian Language Education, English Language Education, Indonesian Literature, or English Literature. They should take training in order to be T\&LILF instructors.

Learning related to cultural aspects for the T\&LILF students was usually carried out on Saturday, namely in the form of field trip visiting several objects such as: traditional markets, orphanages, batik training center, silver manufacturing site (Kota Gede), and others. Some even had done interviews with security guards or teachers. This was a direct Indonesian language exercise and cultural experience as well.

In addition to the above activities, another cultural element that was carried out by USD T\&LILF was by sending students to several international events held in other campus. For example, involving the learners at the International Festival held by UNY every year. In that way, they did not only know the culture of other countries, but also understood the diversity of Indonesian culture because there were several contingents from some provinces.

From the results of interviews and field observations on aspects of T\&LILF learning material in several T\&LILF implementing institutions in Yogyakarta, the following findings were obtained. The T\&LILF in the Indonesian Institute of Arts (ISI) Yogyakarta was managed by the International Affairs Unit which was under the direction of the Secretary of the Rector. The International Affairs Unit 
had a vision of being committed to strengthen international networks. It provided professional support and advised to international students. It helped international students to resolve problems related to the various complexities associated with international partnerships in academic matters. This vision was very helpful not only for foreign students, but also for the whole community within this institution.

T\&LILF classes at ISI were only conducted on one semester, namely in odd semester. The material delivered was often not finished, because the limitation of time. The T\&LILF program only organized two learning levels, namely basic and intermediate level. They did not open advanced class because they were constrained by the teaching resources there. There were four instructors of T\&LIL, two of them from English department and the other two from Indonesian language department. They had absolutely no basic knowledge to be T\&LILF program instructors.

Ahmad Dahlan University (UAD) had three T\&LIFL programs, namely Darmasiswa, Study Program, and Balai Bahasa (selffunded). Scholarships were under the auspices of the Office of International Affairs of UAD. Darmasiswa was a scholarship program offered to all foreign students from countries that had diplomatic relations with Indonesia. This scholarship allowed international students to learn Indonesian language, art, music and crafts.

Teaching materials used in the Darmasiswa T\&LIFL were issued by the National Language Agency, in the form of textbooks entitled Sahabatku Indonesia. For supplement material, the instructor sought other sources related to the material in the textbooks. In this program, the instructor had never developed his/her own teaching material, unlike in the Study Program T\&LILF, where the instructor always developed teaching material.by his/herself.

There were only a few cultural elements conveyed by the instructor while teaching in the class, because there was indeed a course specifically designed to discuss about culture. The material that was usually delivered by the teacher was always related to the language used every day. Not all teaching materials directly carry out practical activities, only certain materials directly practice. For example, material about art, cooking, etc. is the material that is used to conducting practical activities so that students become enthusiastic in learning, because they could move freely and express themselves. Several books from the Language Agency (Sahabatku Indonesia) or other BIPA books had cultural aspects, although they could be added with teaching material that was more related to Javanese local culture, especially Yogyakarta culture

The third aspect was learning media. In UAD T\&LILF, the instructors did not use specific media, unless if the learning material is about local culture products such as wayang, batik, etc. As same as the media, generally, approach-method-strategy, and assessment of T\&LILF had not Indonesian culture-based. The approaches, methods, and learning strategies had not also used learning models that included language learning, language awareness, cultural awareness, and cultural experience. The cultural aspects of T\&LILF learning assessment had not been carried out with process assessment, but some have already packaged them in cultural festivals at the end of the program.

The last aspect was program evaluation. An evaluation should be carried out by every institution hat run a certain program in order to know the output even the outcome of the program. The purpose is to determine the successes and obstacles faced in running the program by doing this, it can be decided whether a certain program should be continued or stopped. There are many systems of program evaluation that can be implemented. For more details, the following part is the presentation of the program evaluation of the T\&LILF in UNY and UII institutions.

Program evaluation had been carried out by the management of UNY T\&LILF. The management of it was in the Office of International Affairs. T\&LILF was one of the divisions in this office. This program was led by a coordinator, and through this coordinator, interviews were conducted to find out the evaluation system done. In addition, interviews were also conducted with one of the teaching staffs.

T\&LILF at UNY carries out various types of programs to support the achievement of institutional goals. Broadly speaking the program managed by this institution was divided into in class and out of class activities. The class program was divided into three program, namely 
cultural language class, Indonesian Language class for academic purposes (BIPATA), and private class programs.

Cultural language class programs were carried out with the aim of teaching Indonesian focused on culture. In this program, teaching did not only focus on knowledge about Indonesian, but it was done as part of culture. It is unlike the BIPATA class program which was carried out in order to have Indonesian language skills for academic purposes. The Indonesian language taught in this program was scientific Indonesian usually used in listening lecture, discussion and oral presentation, reading scientific references, and writing scientific papers.

In addition, student activities in the second semester were cultural camps and the introduction of Javanese culture were carried out in certain villages around Yogyakarta. Students took part in cultural camp activities by taking part in community activities in the village, such as staying in people's homes, participating in plowing fields, caring for livestock and so on. This activity aimed to introduce the way of life of farmers in the villages in Yogyakarta. The introduction of Javanese culture was a separate class taken by students in the second semester. It was also to familiarize Yogyakarta culture.

The other activities were Global Culture Festival, T\&LILF Teacher Training, and losing Ceremony. These activities were carried out regularly every year. Participants from these activities varied, specifically for T\&LILF teacher training. It was carried out nationally and the participants were academics interested in becoming lecturers of, T\&LILF throughout Indonesia. This activity was carried out for two levels, level one and level two.

Furthermore, the Global Culture Festival program was attended by all students in UNY T\&LILF and invitees who came from various regions in Indonesia. This activity was an activity to introduce local specialties and culture. Each student was given the opportunity to introduce cultural products and special foods originating from his country using Indonesian language. In addition, invited participants from various regions in Indonesia were also given space to introduce their culture and regional specialties. This festival was open to the public and can be visited by all groups.
Another program that was also carried out by the management of T\&LILF in UNY was the closing ceremony. This program was held at the end of the second semester as the culmination of the activities of T\&LILF students. This program provided space for each student to display their interest in Indonesia such as poetry, Indonesian regional dances, batik, photography works in various places in Indonesia, and so on. These programs were intended to introduce and bring students closer to Indonesian culture.

Based on information obtained from respondents, the T\&LILF program in UNY was regularly evaluated, and it was conducted once a year. Program evaluation was carried out after the program was implemented. Program evaluation involved leaders, teachers, students, and management staff. While outcome evaluations involving graduate users were rarely done. This evaluation was conducted to determine the sustainability or achievement of the program which had been implemented in one year.

Evaluation was carried out to see the quality of services performed by the management of the UNY T\&LILF. This evaluation involved students and instructors or lecturers. Evaluation of the quality of management services was done using questionnaires and conducting interviews. Regarding the quality of the services, lecturers or teaching staff were also participated in the evaluation meeting forum. The data of evaluations from both the students and the teaching staff were then analyzed and the results were used to improve the quality of institutional services.

Program evaluation was carried out by the T\&LILF management agency in UII. The UII T\&LILF management was one of the business units of UII engaged in language and culture. As a language institution CILACS was responsible to manage Indonesian language courses for foreign speakers. T\&LILF was managed by one of the departments of CILACS called the Research and Development Department. This department not only responsible to solve the problems of the T\&LILF but also to develop it as a business unit.

In addition, the implementation of T\&LILF in UII was still very lacking. It was noted, besides the Indonesian language course activities, only one activity was designed for students, namely the introduction to Yogyakarta culture. As a business unit, CILACS managed 
many programs. Since the T\&LILF program had not shown significant benefits, CILACS had not really focused on developing enough activities for T\&LILF programs.

Cultural aspects in the second language or foreign language learning were very important so they could not be separated. Instead, the cultural aspects should be the basis for learning the second language, including in T\&LILF learning. Therefore, cultural aspects which in this context could be Indonesian culture or local culture, especially Yogyakarta culture, ought to be an aspect included or used as a basis for T\&LILF program in Yogyakarta. This was in line with Kim's (2003) findings on "Exploring the Relationship Between Language, Culture and Identity" in the Gema Online Journal which links the importance of the relationship between the three aspects in language learning, especially second language or foreign language.

The findings of this study were also in line with the findings of Kanoksilapatham (2018) published in Language, Linguistic, and Literature entitled the Local Culture Context-Based English Lesson in Northern Thailand. It was found that language learning $\mathrm{h}$ could not be separated from its cultural aspects, the target language culture or the local culture where learners learn a second language or a foreign language.

\section{Discussion}

The result of quantitative data analysis showed that the six elements of program implementation of T\&LILF namely (1) program management, (2) learning material, (3) learning media, (4) approaches, methods, and strategies, (5) assessment, and (6) program evaluation were in good category. However, deeper investigation using qualitative data indicated that the basis of culture in every aspect has not been considerably well developed. The following discussion adresses the finding relating every element integrated into the existing relevant theories and the previous research findings.

T\&LILF program management had not been fully culture-based. The evidences could be found from the recruitment of lecturers and staff. There was no requirement demanding on the educational background of cultural studies. Whereas, the absence of staff development with the special material regarding to the integration of culture in Indonesian learning as a foreign language would influence on the success in managing and running the program. This is in line with the thought of Mikhaleva \& Régnier (2014) that in the cultural learning, combining the two cultures, namely indigenous culture and target culture are the most appropriate way to do. They call them as a parallel study of culture. That learning model is considered good enough to help learners especially in developing their personalities. Whereas one of the ways to observe their personality changes is to see how the learners make interaction with other people such as their teachers or their friends.

Evidently, learning materials used are not entirely refer to culture. Even though there have been several cultural introductions through various materials, they have not been entirely based on culture. Synthesizing of learner's origin cultures with Indonesian culture have also not been well applied. The cultural synthesis substantively can be done by combining or mixing the elements from the same of two cultures between the cultures of learners and Indonesian culture. The alignment of these two cultures will not only strengthen the two cultural values of the two countries but will also enable to explore the cultural potential that has not been realized before. Additionally, research done by Mediyawati, Lustyantie, \& Emzir (2019) had proven that developing learning materials which were based on multicultural and real life character could support good language acquisition. Cultural synthesis, or alignment of two cultural elements would support the pride of learners in the cultural values of their respective countries and an appreciation of the target culture they learned. However, cultural synthesis does not mean only merging of two cultures, but rather the effort to train the learners' attitudes and sensitivity in appreciating different cultures, which can then form a global perspective. Some experts also said that cultural synthesis is very important in supporting the success of cultural learning. For example, Altstaedter \& Jones (2009) who state that the ability to integrate cultural knowledge including the ability to compare two cultures will help learners gain broader perspectives and help them to form intercultural awareness. In addition, Madya (2013) states that bench marking one's own culture and target culture is the most basic level in the practice of cultural learning. 
Regarding the use of learning media, most of universities conducting T\&LILF have not maximized the existence of digital media. The media commonly used are only visual, audiovisual, and optimizing potential environment. There are many benefits that can be gained indeed when the cultural learning activities maximize the use of digital technology. As Altstaedter \& Jones (2009) had done to find out the understanding of the target culture, they used WebQuests consisting of short-term WebQuests and long-term WebQuests. Learning culture with Web-Quests will be very helpful. It is because there are several parts in that application which can be used by the lecturers such as an introduction, a task, information sources, and description of the process, guidance on how information should be organized, and a conclusion. It is believed than when optimize the digital media, the learning outcomes will be more satisfactory. In line to this issue, the ideas proposed by Morgan \& Cain (2000) showed that using digital media able to support learners develop contexts independently even in dialectic learning. One of the ways that is closest to the learners' lives is e-mailing. It can be used to communicate in a wider scope, in addition, video-conferencing and software those that can also support more interactive learning activities. Yilmaz (2017) also convinced that web-based materials can be used as teaching resources. Moreover, since teaching and learning language is an interwoven process, the internet power might be exploited such as modifying activities, practicing vocabulary acquisition, checking the grammar of the target language, and practicing the main four skills using web-based ICT Tool.

In relation to the application of approaches, methods, and strategies in learning, the cultural learning model offered by Byram \& EsarteSarries (1991) including language learning, language awareness, cultural awareness, and cultural experience is appropriate to apply. This is because cultural learning is different from learning other subjects. Cultural learning is more interpretive and constructive (Hsin, 2003). It means that during the learning process, learners must be able to find out the values that are memorable so that they will carry out the interpretation process naturally and finally able to construct and conceptualize the meaning according to the internal cognitive maps they have.

The assessment of cultural learning is more affective. It is therefore attitudes, cultural assimilated, and cultural awareness must be the main considerations (Madya, 2013). In general, all universities holding T\&LILF do not have a standard of cultural learning assessment. UNY T\&LILF is the only program that gave more attention to the assessment of cultural aspect of learning Indonesian language. It was appearing in the activities done at the end of the program that was Global Culture Festival. T\&LILF participants' achievement has not specifically assessed for learning processes. A good assessment should cover process and product of instruction in order to reflect how far the lesson can be mastered by the leaners as well as how teachers can deliver the teaching materials. This thought is in line to Kartowagiran, Wibawa, \& Alfarisa' (2019:34) explanation that through assessment, it can be monitored how teachers deliver the lesson and how they encouraged the students to learn the lesson can be driven.

To solve this problem, the learning assessment model offered by Byran \& Esarte (1991) can be used as an alternative assessment. Given that cultural learning assessment must also be able to reveal communicative behavior between cultures, then at least three things such as (1) attitudes toward the target language, (2) attitudes towards the target culture, and (3) how their feelings or beliefs towards both need to be considered (Wright, 1999). In line with these thoughts, the culture-based T\&LILF assessment must be based on the principles of cultural learning. Liddicoat (2011) provides an overview of pedagogical principles to support the intercultural understanding of learners, which include: (1) active construction (constructing meaning actively in various contexts) (2) making connections (finding cultural differences and differences in belonging and learned culture), (3) interaction (constantly interacting with the language and culture learned), (4) reflection (involves awareness of how the relationships between all aspects of culture are learned, as well as concepts such as diversity and cultural identity).

The last element that is depicted through this research is evaluation. It has a significant 
impact on a program. The evaluation is used as a measuring tool to determine the implementation of a program run by the institution. From that result, it can be understood whether a program is successful or not. This idea is supported by Suyanto (2018) that evaluation is used to monitor that the program was run on the right tract. Evaluation is also used to decide whether a program can be continued or stopped in that period. Unfortunately, there was no evaluation of the T\&LILF program that explicitly evaluated the program achievements on aspects of understanding, awareness, and experience of Indonesian / regional culture. Therefore, the evaluation system of implementing a culturebased T\&LILF program need to be developed properly.

The results of this study are also related to the results of Said (2010) research on, T\&LILF Unacceptable Collocations by Learners of Indonesian as a Foreign Language and the Implication in Language Learning. Foreign language learners' ability to collocate words that are natural and acceptable in the target language is important in foreign language learning; however, it is notoriously difficult for foreign language learners and sometimes makes them frustrated. The finding shows that there are 176 unnatural Indonesian collocations, some of which are negative transfers of learners' mother tongue. This suggests that direct teaching of collocations should be given special emphasis in teaching Indonesian as a foreign language. In another words, in order to be effective, it must be done using culture-based learning.

This point is also related to the results of Mikheeva, Shapovalov, Ereshchenko, \& Antibas (2018) research that stated second language learning such as T\&LILF that applying the communicative tactics as a basis for teaching a foreign language. The use of a simulated dialogue can promote the optimization of the teaching process and supplementary motivation in learning a foreign language as a communication tool, because the choice of an optimal way of expressing intentions is the communicative need of any person learning a language. Of course, this point is also related to cultural aspects as the basis for T\&LILF.

\section{CONCLUSION}

The results of the study of the six T\&LILF programs organized by six universities in Yogyakarta can be summarized as follows. First, T\&LILF program management has not been culture-based. In the recruitment of administrative and teaching staff there is no requirement for educational background in cultural studies that are expected to be able to manage intercultural learning. Likewise, there has been no development of staff with special material regarding the integration of culture in learning Indonesian as a foreign language. Second, the learning material has not been entirely based on culture. Although there have been several cultural introductions through some materials, not all of them which are based on culture. T\&LILF material in the form of synthesis of learning origin culture with Indonesian has also not been developed. Third, there are not many learning medias that are based on culture, only limited to a number of those which material is taken from Indonesian cultural products. Fourth, approaches, methods, and strategies have not used learning models that include language learning, language awareness, cultural awareness, and cultural experiences. Fifth, the assessment of culture-based learning has not been carried out with process assessment, but some have already packed it in cultural festivals at the end of the program. Sixth, there is no evaluation of T\&LILF programs that explicitly evaluates program achievements in aspects of the internalization of Indonesian/regional culture.

Some suggestions that can be submitted based on this research are as follows. First, T\&LILF program organizers who are the subject of this research need to improve cultural aspects in terms of management, material, media, approaches, methods, and learning strategies, learning assessment, and program evaluation. Second, the second phase of research needs to be done, which focuses on the development of culture-based T\&LILF programs in all aspects. The program needs to be tested for effectiveness so that it can become a reference for implementing T\&LILF programs in universities in Indonesia. This will improve the quality of the existing program in term of emphasizing cultural aspects in the teaching and learning Indonesian as a foreign language. 


\section{ACKNOWLEDGEMENT}

This research had been funded by Graduate School Program, Yogyakarta State University.

\section{REFERENCES}

Altstaedter, L. L., \& Jones, B. (2009). Motivating students' foreign language and culture acquisition through webbased inquiry. Foreign Language Annals, 42(4), 640-657. doi:10.1111/j.19449720.2009.01047.x.

Byram, M., \& Esarte-Sarries, V. (1991). Investigating cultural studies in foreign language teaching: A book for teachers. Clevedon Philadelphia: Multilingual Matters.

Gusnawaty, G. \& Nurwati, A. (2019). A learning model of Bahasa Indonesia as a foreign language based on local intercultural politeness. Cakrawala Pendidikan, 38(1), 141-155. doi:10.21831/cp.v38i1.23164.

Gunawan, W. \& Muhamad, A. (2016). Sahabatku Indonesia: Tingkat C2. Jakarta: Pusat Pengembangan Strategi dan Diplomasi Kebahasaan, Badan Pengembangan dan Pembinaan Bahasa.

Hsin, C. (2013). Language and culture in foreign language teaching. English Teaching Forum, 53(2), 1-19.

Kanoksilapatham, B. (2018). Local contextbased English lessons: Forging Northern Thai knowledge, fostering English vocabulary. 3L: Language, Linguistic, Literature, The Southeast Asian Journal of English Language Studies, 24(2), 127142, doi:10.17576/3L-2018-2402-10.

Kartowagiran, B., Wibawa, E. A., \& Alfarisa, F. (2019). Can student assessment sheets replace observation sheets? Cakrawala Pendidikan, 38(1), 33-44. doi:10.21831/ cp.v38i1.22207.

Kim, L. S. (2003). Exploring the relationship between language, culture and identity. Gema Online: Journal of Language Studies, 3(2), 137-158.
Kusmiatun, A., Suyitno, I., HS, W., \& Basuki, I. A. (2017). Identifying features of Indonesian for speakers of other languages $(B I P A)$ learning for academic purposes. International Journal of Social Sciences and Education Studies (IJSSES), 3(4), 197-207.

Liddicoat, A. J. (2011). Language teaching and learning from an intercultural perspective, the history and theory of language planning. In E. Hinkel (Ed.), Handbook of Research in Second Language Teaching and Learning Volume II (pp. 837-855). New York, NY: Routledge.

Madya, S. (2013). Metodologi pengajaran bahasa: Dari Era Prametode sampai Era Pascametode. Yogyakarta: UNY Press.

Maesaroh, R. \& Ellis, R.A. (2016). Sahabatku Indonesia: Tingkat A2. Jakarta: Pusat Pengembangan Strategi dan Diplomasi Kebahasaan, Badan Pengembangan dan Pembinaan Bahasa.

Mediyawati, N., Lustyantie, N., \& Emzir. (2019). M E D I A: Designing a model of IFL learning materials for foreign workers. Cakrawala Pendidikan, 38(1), 75-89. doi:10.21831/cp.v38i1.22245.

Meilinawati, L. \& Darmayanti, N. (2016). Sahabatku Indonesia: Tingkat C1. Jakarta: Pusat Pengembangan Strategi dan Diplomasi Kebahasaan, Badan Pengembangan dan Pembinaan Bahasa.

Mikhaleva, L. V., \& Régnier, J.-C. (2014). Parallel study of native and targetlanguage cultures in foreign language teaching. Procedia - Social and Behavioral Sciences, 154, 118-121. doi:10.1016/j. sbspro.2014.10.122.

Mikheeva, T. B., Shapovalov, E. Y., Ereshchenko, M., \& Antibas, I. A. (2018). Dialogue communicative structures in teaching foreign language. Ponte, 74(4). doi: doi:10.21506/j.ponte.2018.4.23.

Morgan, C., \& Cain, A. (2000). Foreign language and culture learning from a 
dialogic perspective (Vol. 39). Sydney: Multilingual Matters Ltd.

Novianti, N. \& Nurlaelawati, I.(2016). Sahabatku Indonesia: Tingkat A1. Jakarta: Pusat Pengembangan Strategi dan Diplomasi Kebahasaan, Badan Pengembangan dan Pembinaan Bahasa.

Rakhmawati, S. S. \& Hakim, L. (2016). Sahabatku Indonesia: Tingkat B1. Jakarta: Pusat Pengembangan Strategi dan Diplomasi Kebahasaan, Badan Pengembangan dan Pembinaan Bahasa.

Said, M. (2010). Unacceptable collocations by learners of Indonesian as a foreign language and the implication in language learning. Cakrawala Pendidikan, 29(2), doi:10.21831/cp.v2i2.340.

Senge, P. (2000). Schools that learn. London: Nicholas Brealey Publishing.

Suyitno, I. (2014). Pengembangan bahan ajar Bahasa Indonesia untuk Penutur Asing (BIPA) berdasarkan hasil analisis kebutuhan belajar. Wacana, Journal of the Humanities of Indonesia, 9(1), 62-78.

Suyanto, S. (2018). The implementation of the scientific approach through 5 MS of The Revised Curriculum 2013 in Indonesia. Cakrawala Pendidikan, 37(1), 22-29. doi:10.21831/cp. v37i1.18719.
Taftiawati, M. (2014). Strategi komunikasi pembelajaran BIPA UPI Asal Korea Selatan dalam pembelajaran BIPA tingkat dasar. Bahtera Bahasa: Antologi Pendidikan Bahasa dan Sastra Indonesia, 1(3), 1-8.

Widia, I. \& Sulistyaningsih, L. S. (2016). Sahabatku Indonesia: Tingkat B2. Jakarta: Pusat Pengembangan Strategi dan Diplomasi Kebahasaan, Badan Pengembangan dan Pembinaan Bahasa.

Wiyarsi, A., Hendayana, S., Firman, H., \& Anwar, S. (2015). Collaborative learning to improve preservice teachers' knowledge about chemistry content in the automotive vocational context. Cakrawala Pendidikan, 34(3), 311-321. doi:10.21831/cp.v3i3.7337.

Wright, M. (1999). Influences on learner attitudes towards foreign language and culture. Educational Research, 41(2), 197-208. doi:10.1080/0013188990410207.

Yilmaz, S. E. (2017). The impulse of class tutoring activities evaluated in the light of foreign language teaching methods. International Journal of Languages' Education and Teaching, 5(2), 290-300. doi:10.18298/ijlet.1668. 